\title{
Plágio, gêneros discursivos e sanções sociais
}

\author{
José Elderson de Souza Santos* \\ UFC \\ Mariza Angélica Paiva Brito** \\ UNILAB \\ Mônica Magalhães Cavalcante*** \\ UFC \\ Recebido em: 30/06/2019 \\ Aceito em: 07/12/2019
}

\begin{abstract}
Resumo: Discutiremos as sanções sociais impostas ao plágio relacionando-as ao gênero em que a prática é inserida, embasados em estudos textuais e discursivos. Pressupomos que o plágio coloca sob suspeita tanto a honestidade do autor, quanto as regras de funcionamento que regem a circulação dos textos (PIĖGAY-GROS, 2010), sendo infração às normas de circulação dos gêneros (BAZERMAN, 2005). Assim, analisaremos as sanções impostas a essa prática em diferentes gêneros (canção e notícia), discriminando-as entre positivas/negativas e organizadas/difusas (RADCLIFFE-BROWN, 1970). Cada gênero se organiza a partir de normas distintas, levando-nos a constatar que há possíveis variações da sanção ao fenômeno.
\end{abstract}

Palavras-chave: Plágio. Linguística textual. Gêneros discursivos. Sanções sociais.

\begin{abstract}
We will discuss the social sanctions imposed on plagiarism by relating them to the genre in which the practice is inserted, based on textual and discursive studies. We assume that plagiarism places both the author's honesty and the rules governing the circulation of texts under suspicion (PIĖGAY-GROS, 2010), infringing gender norms (BAZERMAN, 2005). Thus, we will analyze the sanctions imposed on this practice in different genres (song and news), discriminating between positive/negative and organized/diffuse (RADCLIFFE-BROWN, 1970). Each genre is organized according to different norms, leading us to verify that there are possible variations of the sanction to the phenomenon.
\end{abstract}

Keywords: Plagiarism. Textual linguistics. Discursive genres. Social sanctions.

Résumé: Nous discuterons des sanctions sociales imposées au plagiat en les rapportant au genre dans lequel la pratique est insérée, sur la base d'études textuelles-discursives. Nous supposons que le plagiat met en doute l'honnêteté de l'auteur et des règles de circulation des textes (PIÈGAYGROS, 2010), ce que résulte en violation des normes des genres (BAZERMAN, 2005). Ainsi, nous analyserons les sanctions imposées à cette pratique dans différents genres (chanson, nouvelles), en distinguant entre positif/négatif, organisé/diffus (RADCLIFFE-BROWN, 1970). Chaque genre est organisé selon des normes différentes, ce qui nous amène à vérifier qu'il existe des variations possibles de la sanction au phénomène.

Mots clés: Plagiat. Linguistique textuelle. Genres discursifs. Sanctions sociales. 


\section{Considerações iniciais}

O presente trabalho é fruto de pesquisa de dissertação de mestrado desenvolvida junto ao Programa de Pós-Graduação em Linguística (PPGL) da Universidade Federal do Ceará (UFC). No estudo que desenvolvemos, temos investigado o plágio, à luz da Linguística Textual, a partir de arcabouço teórico-metodológico dos estudos textuais e discursivos, buscando: a) refletir, em uma perspectiva sincrônica, sobre as diferentes sanções sociais que o plágio recebe em gêneros diversos, a partir do noticiamento sobre ocorrências do fenômeno em canções (domínio discursivo literomusical), notícias (domínio discursivo jornalístico) e artigos científicos (domínio discursivo científico/acadêmico); b) identificar movimentos de copresença e de derivação acionados pelos locutores para a realização do plágio, propondo marcas que visam à sua camuflagem.

Para tanto, investigamos o plágio discutindo as diferentes sanções sociais impostas a essa prática, em decorrência do gênero em que é inserido, e analisamos suas marcas intertextuais a partir de parâmetros constitucionais e funcionais. Nesse sentido, defendemos que a caracterização do plágio, enquanto prática social, textual e discursiva, pode ser ancorada em dois pilares: o primeiro seria a discussão das sanções sociais dadas à prática; o segundo seria o reconhecimento de um conjunto de marcas intertextuais do plágio resultantes de movimentações realizadas pelos locutores com finalidade de manter o texto-fonte e camuflar o texto-plágio.

Frente a esses dois caminhos de investigação apontados acima, este artigo se constitui, de maneira específica, relacionado à busca por refletir sobre as diferentes sanções sociais que o plágio recebe conforme o gênero em que a prática é inserida. Assumimos como pressuposto desta discussão a síntese de Piègay-Gros (2010) dos processos intertextuais. A autora afirma que o plágio coloca em xeque não somente a honestidade do autor, mas também as regras de funcionamento que regem a circulação dos textos.

A fim de testar a hipótese de que é possível apontar tendências distintas de sanções ao plágio e de que tais sanções estão relacionadas às diferentes normas dos gêneros, então infringidas pela apropriação indébita, analisamos acusações de plágio nos gêneros canção e notícia, vinculadas, respectivamente, aos domínios discursivos literomusical e 
jornalístico. Como apoio teórico para as sanções, seguimos a proposta de Radcliffe-Brown (1970), que as distingue entre sanções organizadas (avaliações proferidas por entidades, como as jurídicas e administrativas) ou difusas (avaliações proferidas por sujeitos de forma individual), que podem ser positivas ou negativas. Nosso caminho de análise parte do noticiamento das acusações de plágio. ${ }^{1} \mathrm{Na}$ análise do fenômeno no gênero canção, as sanções organizadas são investigadas a partir da notícia que discute o ocorrido, já as sanções difusas são investigadas a partir da interação de sujeitos que discutem, na plataforma Youtube, a acusação de plágio na canção. Na análise do fenômeno no gênero notícia, as sanções organizadas e difusas são investigadas a partir da própria notícia de acusação.

Para discutir as questões propostas, faremos inicialmente uma abordagem histórico-social do plágio, visto que, embora esse fenômeno não tenha nascido como objeto de investigação científica na Linguística Textual, a área passou a incorporar, acomodando a seu programa teórico-metodológico (principalmente sobre intertextualidade²) estudos como o de Genette (2010) e Piègay-Gros (2010). Em seguida, adentrando o propósito específico deste artigo, fundamo-nos em Bakhtin (1997), Bazerman (2005), Marcuschi (2008) para tecer considerações sobre os condicionamentos de produção, recepção e circulação dos gêneros discursivos. Tomando como base Radcliffe-Brown (1970), discutiremos as noções de sanções sociais que regulam a prática de plágio em cada tipo de gênero que selecionamos.

\section{O plágio como fenômeno social}

Apesar de ser intrínseca hoje a associação do plágio a um fenômeno que ocorre envolvendo textos (embora não somente³), ao longo da história nem sempre tal relação

\footnotetext{
${ }^{1}$ Acreditamos ser possível partir do noticiamento das acusações, pois, conforme Fischer (2013), a mídia, ao manifestar informações, expressa a interpelação que sofre por forças que emergem do social. Assim, consideramos que tais noticiamentos nos permitem realizar observações de como as ideologias de determinados domínios discursivos influenciam a aceitação e o sancionamento do plágio.

${ }^{2}$ Cf. Koch, Bentes e Cavalcante (2008), Cavalcante e Brito (2011), Cavalcante (2012), Nobre (2014), Souza Santos e Nobre (2019).

${ }^{3}$ Chaves (1981) nos fala de plágio em âmbitos diversos, envolvendo, ou não, textos, como na literatura, nos aproveitamentos de eventos históricos, em obras dramáticas, no meio musical, em obras de arte figurativas (como nas artes plásticas), em obras arquitetônicas, em histórias em quadrinhos, em obras científicas, técnicas e didáticas e no meio culinário. Como se pode notar, nos "tipos" de plágio por nós destacados em itálico, esse fenômeno ocorre não envolvendo texto, mas manifestações de outra ordem, que não necessariamente linguísticas. Uma obra arquitetônica, como um prédio, por exemplo, Revista Investigações, Recife, v. 32, n. 2, p. 571 - 602, Dezembro/2019
} 
se deu de maneira inequívoca. Ao ser colocado no escopo de estudos literários os de Genette (2010) e Piègay-Gros (2010), tal objeto se torna passível de análise pelos pesquisadores da área. Dentro da Linguística Textual, retomamos Christofe (1996), pesquisadora que, sob a orientação da professora Ingedore Grunfeld Villaça Koch, estudou o plágio como fenômeno não somente social, mas principalmente linguístico, buscando estreitar as relações entre essas concepções, sociais e linguísticas, do fenômeno.

O retorno ao percurso histórico, porém, deixa claro que, sendo abordado, ou não, pelos pesquisadores da Linguística Textual, o plágio (conforme entendido socialmente hoje) sempre existiu na sociedade, tendo ganhado expressividade como prática ilícita entre os séculos XVII e XIX. A partir disso, argumentamos que a Linguística Textual não pode deixar de incluir em seu programa de investigação um fenômeno que impacta tão fortemente, e há séculos, as práticas sociais mediadas por textos. Diante dessa realidade, acreditamos que esse ramo da Linguística tem papel fundamental na compreensão do fenômeno, que é corriqueiramente debatido nas questões de interpretação e de produção textual, seja no ensino básico, nos meios científico/acadêmico, literário, forense ${ }^{4} \mathrm{ou}$ jurídico. Uma abordagem textual-discursiva do plágio, apesar de não ter o poder de consumá-lo, pode contribuir para a compreensão de como ele se organiza em nossa sociedade, e, assim, incentivar que seja evitado e coibido. Certamente, a apropriação indébita não deve ser incentivada como prática intertextual produtiva (como podem fazer crer as ocorrências investigadas), entretanto defendemos que somente a compreensão dessa prática em sua profundidade fará com que seja desestimulada.

Consoante Christofe (1996), o plágio pode ser observado nas mais diversas produções de linguagem durante a história, tendo seus primeiros registros na Roma Antiga (sob a ótica do direito romano), como ato de apropriação indevida de homens livres ou escravos libertos. Ali, o termo não se referia ainda a uma ocorrência de roubo ou apropriação de produções textuais e ideias. O fato é que as noções de roubo e/ou apropriação se mantiveram ao longo dos séculos, variando apenas quanto àquilo de que as pessoas se apropriavam e quanto às possibilidades de sanções possíveis de serem

não é em sua essência um texto, apesar de poder, em determinado momento (como numa exposição com finalidade artística), ocupar essa posição.

${ }^{4} \mathrm{Cf}$. Sousa-Silva e Abreu (2015).

Revista Investigaçũes, Recife, v. 32, n. 2, p. 571 - 602, Dezembro/2019 
imputadas ao fenômeno. As noções de roubo e apropriação indébita são associadas ao plágio até os dias atuais.

Somente no século XIX, de maneira mais precisa, o plágio é juridicamente associado a texto e/ou a ideias. Christofe (1996) esclarece que o plágio só se tornou crime quando passou a produzir prejuízos econômicos aos autores de textos; antes, porém, esta prática era reconhecida e corriqueira, contudo, não criminosa, sendo recorrente nas produções literárias. A movimentação intertextual que hoje se concebe como plágio, portanto, visto anteriormente ao século XIX, antes de ser conceituado como prática criminosa, apresentava-se inquestionavelmente como processo intertextual produtivo, uma repetição não condenável de textos ou de partes. Os textos eram colocados em diálogo para que os propósitos projetados pelos locutores viessem a ser alcançados, sem necessidade de atendimento a "normalizações intertextuais", que buscassem explicitar, por exemplo, a diferença entre plágio e outros processos intertextuais, como citações e paráfrases. Dessa forma, ao se colocar textos em diálogos intertextuais, não havia necessidade de marcação da autoria, aspeamento, referência, negrito, itálico, ou qualquer outra indicação que se justificasse pela busca de evitar o plágio.

Naquele século, popularizava-se a impressa, fundada por Johannes Guttenberg em 1440. E, com isso, as produções textuais escritas e as ideias (que poderiam vir a se tornar produções textuais escritas) passam, então, a ser observadas como mais uma possibilidade de ganho monetário, pois os textos começam ser comercializados por meio de jornais ou mesmo de livros. Com a necessidade de se reconhecer as primeiras relações de autoria, no século XIX, o plágio passou a ter um caráter juridicamente mais próximo do que conhecemos hoje.

Assim, por uma análise histórico-social do plágio, fica claro que tal conceito tem ampla relação com questões de poder que envolvem obra e autor. Constatamos, por conseguinte, que socialmente ganhou força, durante os séculos, o valor de responsabilidade autoral: os sujeitos são responsáveis pelos textos que produzem. Assim como ganhou força também a condição de que autor corresponde a uma posição de poder no meio social, alcançada por determinados sujeitos.

Com foco nessas relações autor e obra, Barthes (2004) afirma que a noção de autor é uma construção moderna, estreitamente ligada ao contrato capitalista. Dessa forma, a 
relevância das produções se centra em uma imagem que, a partir da obra, adquire determinados privilégios e, muitas vezes, ganhos financeiros.

Foucault (2001), ao questionar o que seria um autor, discorre sobre as relações entre a posição que este exerce na sociedade e o status de poder. Tais relações se ligam não somente à figura do autor, mas à própria obra. Ser um autor é, dessa maneira, ocupar papel social de destaque construído a partir do conjunto de suas produções; como uma via de mão dupla, é, portanto, a obra que dá poder ao autor, esta passa a ser reconhecida como relevante, tendo em vista a posição de prestígio ocupada por aquele.

$\mathrm{O}$ ato de plagiar passa a existir exatamente no centro dessa discussão, levando-se em consideração as posições de poder envoltas em determinadas obras. Um autor, seja reconhecido ou mesmo desconhecido, apropria-se das produções de um outro, considerando o prestígio que elas lhe poderão conceder. O autor tido como o responsável original da obra, por sua vez, reivindica o poder e o prestígio que o outro poderia adquirir com o plágio.

Cabe esclarecer que, na atualidade, o plágio pode ser considerado crime com base na lei n⿳0 10.695 , de $1^{\circ}$ de julho de 2003 , que trata da propriedade intelectual ${ }^{5}$. Munhoz e Diniz (2011) defendem ser importante considerar, no direito, o plágio não como objeto de sanção penal, mas como infração ética. Diniz e Munhoz (2011) assim comentam sobre o fenômeno: "Ele não deve ser entendido como um crime, exceto se houver direitos autorais envolvidos. Nem toda obra é protegida por direito autoral ${ }^{6}$, muito embora todo texto possua uma autoria." (p. 14).

Consideramos, a partir da argumentação das autoras, que nem sempre o plágio se constituirá como um desrespeito às leis. O plágio é, sobretudo, uma prática socialmente sancionada, porque incide sobre as entidades (autor e obra) constituídas, ao longo da história, como passíveis de deter direitos, devido às relações de poder aí envolvidas. Assim,

\footnotetext{
${ }^{5} \mathrm{Na}$ lei, em momento algum o termo plágio se encontra posto materialmente, assim como o de contrafação (ato de se apropriar da obra de outro e, com isso, adquirir benefícios financeiros - o plágio, diferentemente da contrafação, não implica, necessariamente, aquisição de benefícios financeiros), entretanto, as conceituações a ele ligadas são apresentadas, como "[...] reprodução total ou parcial, com intuito de lucro direto ou indireto, por qualquer meio ou processo, de obra intelectual, interpretação, execução ou fonograma, sem autorização expressa do autor, do artista intérprete ou executante, do produtor, conforme o caso, ou de quem os represente." (lei no 10.695 , de $1^{\circ}$ de julho de 2003). Não há, na abordagem presente na lei, uma diferenciação conceitual entre contrafação e plágio, o que se distancia do entendimento de Chaves (1981).

${ }^{6} \mathrm{Cf}$. artigo 184 do código penal brasileiro.
}

Revista Investigaç̃̃es, Recife, v. 32, n. 2, p. 571 - 602, Dezembro/2019 
o plágio seria, principalmente, um desrespeito ao direito do autor e à obra, podendo figurar e vir a ser punido como um desrespeito às leis.

Ao estudar o plágio na Linguística Textual, não nos compete tomar posicionamentos sobre as acusações de plágio, nem acusar tal prática de "certa" ou "errada", tampouco buscamos saber se os autores, ao se utilizarem de tal prática intertextual, tiveram intenção delituosa (condição especulativa de difícil aferição partir de parâmetros científicos). Temos ciência de que, frente a múltiplos outros processos intertextuais que cumprem tão bem funções argumentativas na sociedade, sem infração de regras, o plágio não pode ser considerado, de fato, como um fenômeno descritivamente produtivo. Consideramos, aqui, que as sanções sociais impostas ao plágio, advindas da compreensão social desse fenômeno como infrator, irão emergir em decorrência das normas de circulação dos gêneros em que tal prática se insere. Parece-nos que os sujeitos, imersos em comunidades discursivas distintas, concebem o fenômeno também de maneiras distintas, independentemente de sua estrutura de realização. Assim, o que se considera como plágio em um artigo científico, poderia não o ser em uma canção, ou em uma notícia.

Talvez seja possível considerar ainda que os plagiadores, conscientes (ou não) dessa realidade, manipulam os intertextos de plágio para evitar que eles sejam reconhecidos como tais, bem como podem manipular ainda os argumentos mobilizados em sua defesa levando em consideração o domínio discursivo em que se encontra o caso sob acusação ${ }^{7}$. Uma ideia interessante é pensar quais traços são manipulados para esconder o roubo de autoria, mas que acabam por explicitar tal prática.

\section{Domínios discursivos, gêneros do discurso e sanções sociais}

Apesar de ser uma prática renegada socialmente, de modo geral, as pessoas costumam enxergar a ocorrência do plágio de maneiras distintas, o que traz consequências também distintas para as sanções, inclusive as administrativas e as jurídicas, que recebe no meio escolar, acadêmico, artístico etc. Isso se dá devido à

\footnotetext{
${ }^{7} \mathrm{Se}$, de fato, a percepção social quanto às ocorrências de plágio estiver ligada aos domínios (e mais precisamente aos gêneros) em que os casos se encontram, é possível projetar que as argumentações, sejam de defesa, sejam de acusação, mobilizadas em torno das ocorrências, tendem a alcançar mais facilmente os objetivos projetados ao levarem em consideração as ideologias dos domínios discursivos, antecipando possíveis reações dos sujeitos.
}

Revista Investigações, Recife, v. 32, n. 2, p. 571 - 602, Dezembro/2019 
influência, nos sujeitos, de ideologias (valores ideológicos, modos de pensar e crenças que compõem bases para sustentação de posicionamentos) que constituem os domínios discursivos, que acabam por direcionar seus posicionamentos e comportamentos. Além disso, convém considerar que o plágio geralmente desperta uma polêmica, e, sempre que vem à tona, faz emergir também questões éticas, estimulando o engajamento dos sujeitos, os quais se posicionam frente às ocorrências, defendendo-as ou acusando-as.

Os gêneros que circulam numa sociedade, como os das comunidades citadas no parágrafo anterior, por sua vez, floresceram junto a um conjunto de normas passíveis de serem associadas às ideologias dos domínios discursivos a que se agregam, ou seja, se organizam vinculados a diferentes formas de compreender, avaliar e realizar práticas discursivas distintas manifestadas em textos. Assim, acreditamos ser possível considerar que, por mais que a prática de plágio tenha sido constitucionalmente realizada (condição aferível pelas marcas e movimentos de camuflagem, sobretudo intertextuais, expressos no contexto de realização do fenômeno), os sujeitos, ao terem acesso àquele texto, automaticamente o associam às normas de circulação do gênero em que a prática se insere. Como tais normas são construídas sócio-historicamente e estruturadas por meio de domínios discursivos, criam-se diferentes sanções à prática do plágio. Além disso, cabe considerar que ocorrências de plágio, sempre polêmicas, podem, por exemplo, receber variados graus de sanções, associadas a gêneros específicos, em domínios específicos, ou até mesmo sanções divergentes entre si dentro de um mesmo gênero e domínio. Faz-se, então, essencial tratarmos dos domínios discursivos, das noções de gêneros, de suas normas de circulação e das sanções sociais. Para tanto, ancoramo-nos em Marcuschi (2008), Bakhtin (1997), Bazerman (2005), e Radcliffe-Brown (1970).

\section{Sobre domínios discursivos}

A fim de compreender como as ideologias, "formações históricas e sociais" (MARCUSCHI, 2008, p. 158), norteiam os discursos e comportamentos dos sujeitos conforme o local de onde esses se manifestam, tratamos, neste ponto, de noções ligadas ao conceito de domínio discursivo, trabalhadas por Marcuschi (2008). O autor aborda 
esse conceito de forma objetiva e clara, realizando ligações entre tal noção, o surgimento e circulação dos gêneros textuais ${ }^{8}$. O estudioso assim nos esclarece:

Domínio discursivo constitui muito mais uma 'esfera da atividade humana' no sentido bakhtiniano do termo do que um princípio de classificação de texto e indica instância discursiva (por exemplo: discurso jurídico, discurso jornalístico, discurso religioso etc.). Não abrange um gênero em particular, mas dá origem a vários deles, já que os gêneros são institucionalmente marcados. Constituem práticas discursivas nas quais podemos identificar um conjunto de gêneros textuais que às vezes lhe são próprios ou específicos como rotinas comunicativas institucionalizadas e instauradoras de relações de poder. (MARCUSCHI, 2008, p. 155, grifo do autor).

Tratar dessa noção é pertinente e necessário, pois ela nos ajuda a explicar o porquê de, apesar de o plágio ser uma prática renegada socialmente, de modo geral, os sujeitos, conforme os domínios discursivos dos quais se manifestam, enxergarem a produção e interpretarem a prática distintamente. Isso se daria, pois, conforme o autor frisa, cada domínio discursivo se estrutura sócio-historicamente em torno de regras, normas e práticas discursivas distintas. Essa realidade nos leva a crer que as manifestações textuais realizadas sobre o cerco de tais domínios estejam sempre suscetíveis, durante suas produções e interpretações, aos "filtros" ideológicos dos domínios em que efetivamente ocorrem. Dessa forma, as manifestações textuais estão suscetíveis às disposições prévias (constituídas sócio-historicamente), que se expressam de maneiras mais ou menos recorrentes, de interpretação, avaliação e/ou produção de fenômenos linguísticos (sobretudo textuais e discursivos), a que os sujeitos estão submetidos ao interagirem através de gêneros discursivos vinculados a comunidades específicas.

\footnotetext{
${ }^{8}$ Nos referimos, ao longo deste trabalho, a "gêneros discursivos", ou "gêneros do discurso"; Marcuschi (2008), por sua vez, se utiliza da expressão "gêneros textuais". Não concebemos, assim como o autor, diferenciação entre as três expressões. O pesquisador assim esclarece: "Não vamos discutir aqui se é mais pertinente a expressão 'gênero textual' ou a expressão 'gêneros discursivo' ou 'gêneros do discurso'. Vamos adotar a posição de que todas essas expressões podem ser usadas intercambiavelmente, salvo naqueles momentos em que se pretende, de modo explícito e claro, identificar algum fenômeno específico." (MARCUSCHI, 2008, p. 154). Temos ciência, entretanto, que alguns autores concebem diferenciações entre tais termos, a exemplo de Zavam (2017). A autora, ao tratar da questão, argumenta que "De um modo geral, os estudos que se voltam à descrição da composição e da materialidade linguística adotam 'a teoria dos gêneros textuais'; e os que se centram na descrição da situação de enunciação e em seus aspectos sócio-históricos, a 'teoria dos gêneros do discurso' (ROJO, 2005)." (ZAVAM, 2017, p. 09).
}

Revista Investigações, Recife, v. 32, n. 2, p. 571 - 602, Dezembro/2019 


\section{Sobre gêneros do discurso}

Bakhtin (1997), em "Estética da criação verbal”, aborda o que denomina gêneros do discurso. Para o autor, em todas as esferas sociais, encontramos a utilização da língua. Tal utilização, entretanto, não se dá de maneira única, muito menos aleatória. A organização da manifestação linguística se constrói a partir de estilos, conteúdos, temáticas, tendo em vista a esfera específica de comunicação. Em uma perspectiva dialógica, o filósofo soviético destaca que os enunciados estão sempre em diálogo uns com os outros e, assim, devem ser analisados, não isoladamente.

O enunciado reflete as condições específicas e as finalidades de cada uma dessas esferas, não só por seu conteúdo (temático) e por seu estilo verbal, ou seja, pela seleção operada nos recursos da língua - recursos lexicais, fraseológicos e gramaticais - , mas também, e sobretudo, por sua construção composicional. Estes três elementos (conteúdo temático, estilo e construção composicional) fundem-se indissoluvelmente no todo do enunciado, e todos eles são marcados pela especificidade de uma esfera de comunicação. Qualquer enunciado considerado isoladamente é, claro, individual, mas cada esfera de utilização da língua elabora seus tipos relativamente estáveis de enunciados, sendo isso que denominamos gêneros do discurso. (BAKHTIN, 1997, p. 279, grifo do autor).

Bazerman (2005), na esteira das reflexões bakhtinianas, em sua obra "Gêneros textuais, tipificação e interação", analisa os atos de fala, gêneros textuais e sistemas de atividades, debruçando-se sobre como os textos organizam atividades e pessoas. Os estudos realizados pelo autor apontam para uma relação estreita dos gêneros com o social, não somente por ser a língua e os gêneros instâncias dialógicas, mas porque "cada texto se encontra encaixado em atividades sociais estruturadas e depende de textos anteriores que influenciam a atividade e a organização social.” (BAZERMAN, 2005, p. 22). Com Bazerman (2005), compreendemos que os gêneros se encaixam em um sistema de regras e normas (padrões de organização dos textos, comportamentos e interações dos sujeitos, não estanques, rígidos ou normativos, mas recorrentes), pelos quais não somente são regidos, mas também regem as condutas sociais.

Os gêneros são produzidos almejando-se atingir determinados objetivos, como afirma Bazerman (2005, p.22): “Compreender os atos e fatos criados pelos textos pode Revista Investigações, Recife, v. 32, n. 2, p. 571 - 602, Dezembro/2019 
[nos ajudar] também a compreender quando textos, aparentemente bem produzidos, não funcionam, quando não fazem aquilo que precisam fazer.” Pensamos que a prática de plágio constitua exatamente um desses casos em que os textos e os respectivos gêneros violam suas normas. O plágio deturpa os padrões de organização das relações entre textos esperados em produções textuais (comumente colocadas em diálogo por meio de processos intertextuais que não o plágio ${ }^{9}$ ), vindo, dessa forma, a desestabilizar as relações de poder entre os autores e obras envolvidas na existência do fenômeno. Assim, apropriação indébita figura, portanto, como prática socialmente desprestigiada e, generalizadamente, não lícita. Essa realidade estimula que os sujeitos avaliem tal transgressão em consonância com as permissibilidades do domínio em que se inserem.

Para Marcuschi (2008, p.161), em seu livro "Produção textual, análise de gêneros e compreensão", "os gêneros são atividades discursivas socialmente estabilizadas que se prestam aos mais variados tipos de controle social e até mesmo ao exercício de poder". Analisamos que, nas situações de plágio, tal controle social irá variar de acordo com o gênero analisado. Nesse sentido, não é somente os variados processos intertextuais que, inseridos nos textos, produzem efeitos de sentidos diversos; os efeitos de sentidos diversos são decorrentes, também, dos diferentes gêneros textuais em que as relações intertextuais são inseridas.

A título de exemplo, podemos afirmar que a utilização de uma citação, uma paráfrase ou uma alusão, certamente pode alterar os efeitos de sentidos projetados pelo locutor, ao inserir algum desses processos intertextuais em seus textos. Se pensarmos em um efeito de sentido como o recurso à autoridade, esse, por vezes, pode ser fortalecido com uma citação, se tornando menos expressivo, em uma paráfrase e, ainda menos, em uma alusão. Ao vincularmos a utilização de processos intertextuais a gêneros, podemos pensar que, por exemplo, a construção de um texto parodístico, tal qual explica Sant’Anna (2003), é muito mais comum em gêneros vinculados ao domínio literomusical que em gêneros vinculados ao domínio científico/acadêmico. Influencia tal realidade o fato de esse mesmo processo intertextual, a paródia, originar efeitos de sentidos muito mais esperados no meio literomusical que no meio científico/acadêmico.

${ }^{9}$ No âmbito das intertextualidades, essa é exatamente a prática que deve ser evitada. Revista Investigações, Recife, v. 32, n. 2, p. 571 - 602, Dezembro/2019 
Não estamos dizendo, com essa discussão, que os gêneros determinam todas as escolhas de organização textual. Como afirma Marcuschi (2008):

[...] podemos dizer que o controle social pelos gêneros discursivos é incontornável, mas não determinista. Por um lado, a romântica ideia de que somos livres e de que temos em nossas mãos todo o sistema decisório é uma quimera, já que estamos imersos numa sociedade que nos molda sob vários aspectos e nos conduz a determinadas ações (MARCUSCHI, 2008, p.162).

Seguindo essa linha de raciocínio, levantamos a hipótese de que o plágio, em qualquer que seja o gênero, é sempre visto como uma transgressão às práticas sociais mediadas pelo texto (já que, como argumentamos, frente aos demais processos intertextuais, não é esperado e valorizado), entretanto, consideramos que as avaliações a essa prática, mesmo que enxergada como transgressão, não são uniformes, vindo a variar em decorrência da comunidade discursiva e gêneros do discurso em que se manifestam as ocorrências. Nesse sentido, quando os sujeitos argumentam, por exemplo, que determinada ocorrência, apontada como plágio, não o seria (mesmo que essa tenha sido avaliada pela justiça como tal, e sua constituição, aferível através da análise da relação entre textos, valide esse entendimento), esses buscam distanciar da ocorrência seu caráter transgressor, por compreenderem que plagiar é atitude desprestigiada.

Defendemos, dessa forma, que, sendo o controle social imposto ao gênero uma realidade incontornável, conforme defende Marcuschi (2008), qualquer percepção de transgressão ao gênero recebe sanções sociais (avaliações, quer aprovativas, quer reprovativas), em maior ou menor grau. $\mathrm{O}$ falante que, por exemplo, não atende aos comportamentos e modos de interagir esperados no gênero entrevista de emprego pode ser punido através da não contratação; o plágio inserido em uma canção pode nem ser considerado como tal, porque a apropriação pode ser vista aí como uma licença poética (o que representa uma sanção positiva). Já no gênero a artigo científico, dificilmente essa prática será tomada da mesma maneira, podendo levar a sanções sociais negativas mais severas, como perda do título acadêmico, processos e exposição pública; no meio jornalístico, por sua vez, as normas do gênero notícia podem anular (ou desestimular) 
sanções a ocorrências de plágio $^{10}$. Mostra-se, assim, pertinente a relação que tecemos entre gêneros e sanções sociais.

\section{Sobre sanções sociais}

Radcliffe-Brown (1970) define, em seu texto "Sanções sociais", que toda comunidade é constituída por costumes sancionados, quer de maneira mais particular, pelos indivíduos que a compõem, quer por ocupantes de posição de autoridade, como conselhos jurídicos ou sindicâncias administrativas. Tais sanções podem ser positivas, de caráter aprovativo (valorização de determinadas práticas e comportamentos, premiações etc.), ou negativas, de caráter reprovativo (desvalorização e crítica a determinadas práticas e comportamentos, acusações a atos como ilícitos, criminosos etc.). Sanções, nesse contexto, seriam, portanto, avaliações de membros e instituições de uma sociedade, ou de parte dela, a determinadas práticas.

Dentre os tipos discutidos pelo autor, estão as difusas e as organizadas. As difusas ocorrem de maneira pontual, por um indivíduo específico sobre outro ou por um número determinado de indivíduos sobre outros. As organizadas, por sua vez, seriam sanções reconhecidas socialmente e superestimada por maior parte do conjunto social, proferidas, muitas vezes, por instituições, tribunais, conselhos, juris etc. As sanções organizadas, provavelmente, nasceram de sanções sociais difusas que, com o tempo, se solidificaram e adquiriram considerável prestígio.

As sanções existentes numa comunidade constituem motivos no indivíduo para a regulação de sua conduta em conformidade com o costume. Elas são efetivas, primeiro, pelo desejo do indivíduo de obter a aprovação e evitar a reprovação de seus semelhantes, de ganhar as recompensas ou evitar os castigos que a sociedade oferece ou aplica, e, segundo, pelo fato de aprender o indivíduo a reagir a modos particulares de comportamento com juízos de aprovação e reprovação do mesmo modo como os seus semelhantes e, portanto,

\footnotetext{
${ }^{10}$ Entretanto, ainda assim, é possível encontrar ocorrências nas quais a prática foi constatada, averiguada e sancionada. A exemplo, destacamos o caso da ex-jornalista Joice Hasselmann, e atual parlamentar do Partido Social Liberal (PSL), à época funcionária da Veja, que, conforme diversas notícias divulgadas na web (aqui apresentamos a veiculada pelo Sindicato dos Jornalistas Profissionais do Paraná. Disponível em: <http://www.sindijorpr.org.br/noticias/6066/conselho-de-etica-comprova-plagio-praticado-pelajornalista-joice-hasselmann>. Acesso em: 07 set. 2018), teria sido acusada por 23 jornalistas de realizar plágio de 65 reportagens. Acreditamos que tal caso tenha ganhado repercussão, dentre outros fatores, pelo fato de a jornalista supostamente plagiar um número expressivo de textos.

Revista Investigações, Recife, v. 32, n. 2, p. 571 - 602, Dezembro/2019
} 
medir seu próprio comportamento, quer por antecipação, quer em retrospecto, por padrões que se conformam mais ou menos estreitamente com os que prevalecem na comunidade a que pertence. (RADCLIFFE-BROWN, 1970, p.1).

Conforme destaca o estudioso, as sanções, em uma sociedade, regulam as práticas nela existentes. Os indivíduos, temerosos de sofrerem sanções sociais negativas ou com foco em receberem sanções sociais positivas, comportam-se de determinadas maneiras. Assim, Radcliffe-Brown (1970) pontua que há sempre uma projeção, por parte dos sujeitos, de quais práticas eles podem realizar e quais sanções essas práticas acarretariam. Dentre as diversas sanções possíveis, no texto o autor dá destaque às sanções criminais do direito, que se constituem como mecanismos de controle social. Quanto à função de tais práticas, salientamos que, sob a ótica textual, o efeito delas recai nunca sobre o autor empírico, mas sobre a imagem construída desse sujeito na sociedade.

\section{A variação das sanções em decorrência do gênero em que se insere a prática de plágio}

A análise presente nesta seção tem o intuito de mostrar como pode haver, em torno de uma ocorrência de plágio, diferentes sanções à prática, sobretudo quando comparamos as sanções organizadas e difusas impostas às ocorrências. Compreendemos que, sendo o plágio infração ética e processo desprestigiado, o esperado é que, enquanto prática não lícita, as ocorrências desse fenômeno sejam sancionadas negativamente na sociedade, tanto em âmbito organizado, como em âmbito difuso (com exceção, claro, dos sujeitos diretamente envolvidos com a ocorrência alvo da acusação, sobretudo o plagiador, que, costumeiramente, em ato de defesa, negam ter realizado a prática). Entretanto, se o plágio é uma prática não lícita, por que há casos em que o fenômeno recebe sanções positivas, ou, apesar de ser reconhecido em termos de constituição, tampouco é sancionado coletivamente? Consideramos ser possível atrelar a resposta a essa pergunta aos gêneros (e domínios discursivos) em que se dão os casos analisados, conforme discutimos até aqui.

Demonstraremos que essa variação de sancionamentos se dá da seguinte forma: 1) analisamos uma acusação de plágio presente no domínio discursivo literomusical, no gênero canção, em que o texto "O careta", de Roberto Carlos, foi acusado e punido judicialmente por se constituir como plágio da canção Loucuras de amor, de Sebastião 
Braga; 2) analisamos uma acusação de plágio encontrada no domínio discursivo jornalístico, no gênero notícia. O caso foi noticiado pelo Jornal Opção (Goiás), que, por sua vez, acusou o jornal O Popular (Goiás) de ter plagiado uma de suas notícias. Com essas análises, não temos como intuito generalizar as conclusões de análise a todas as ocorrências de plágio, entretanto, acreditamos ser possível apontar uma tendência, argumentada até então, de que as sanções sociais impostas à prática de plágio variam conforme o gênero (e domínio discursivo) em que se dão os casos.

\section{Caso I: acusação de plágio no gênero canção}

Nossa investigação se inicia com a notícia, publicada no site do Supremo Tribunal de Justiça (STJ), no qual o tribunal confirma a ocorrência de plágio e nos apresenta aquilo que compreendemos como sanção organizada imposta à prática. Em seguida, nos debruçamos efetivamente sobre um vídeo publicado no Youtube, por um de seus usuários, em que se pode ouvir a música de Sebastião Braga; o vídeo questiona se a canção de Roberto Carlos teria sido "plágio ou coincidência”. A partir de tal questionamento, outros usuários da rede se mobilizaram defendendo ou atacando a acusação, proferindo, assim, sanções (julgamentos) difusas (individuais) - positivas ou negativas. Por fim, apresentamos a parte verbal de trechos do suposto texto-fonte e do suposto texto-plágio, a fim de apontar, por meio da organização da versificação das partes em questão, o possível movimento de reprodução em âmbito melódico.

É preciso esclarecer que, no exemplo analisado, não é possível aferir com exatidão os movimentos intertextuais apropriados pela ocorrência de plágio, que levaram à acusação. Isso se dá porque a acusação de plágio envolveu não a parte verbal escrita das canções, mas a parte melódica. Desse modo, as músicas têm letras completamente distintas, entretanto, estruturas melódicas (compassos) semelhantes. Assim, partimos do pressuposto da existência da prática devido à condenação jurídica. Ao final deste tópico de análise, apresentamos os trechos dos textos enquadrados juridicamente como envolvidos na situação de plágio, buscando apontar, por meio da distribuição da versificação, a semelhança melódica entre os trechos, o que pode contribuir para a compreensão da ocorrência.

Vejamos, a seguir, a notícia divulgada no site do STJ sobre o caso: 
Figura 1 - Notícia divulgada no site do STJ sobre condenação, por plágio, de Roberto Carlos, na canção O careta

STJ mantém decisão que condenou o cantor Roberto Carlos por plágio

O ministro Ruy Rosado de Aguiar, do Superior Tribunal de Justiça (STJ), negou provimento ao agravo de instrumento (tipo de recurso) do cantor e compositor Roberto Carlos que pretendia o reexame pelo STJ da decisão que o condenou por plágio. O Tribunal de Justiça do Rio de Janeiro confirmou que a música "O Careta", lançada por Roberto Carlos em 1987 pela gravadora CBS é plágio da canção intitulada "Loucuras de Amor", de autoria do compositor Sebastião Braga. A disputa pela titularidade da música "O Careta" teve início no STJ em 1995, e neste período, oito recursos foram interpostos para análise do caso. Sebastião Braga ajuizou a primeira ação em primeira instância em 1990, com base na Lei do Direito Autoral (Lei 5.988/73), quando pediu o reconhecimento do plágio, a publicação em jornal de grande circulação de material reconhecendo sua autoria, a inserção de seu nome nas gravações ainda não distribuídas, além de indenização por danos moral e material. A ação foi julgada procedente em primeira e segunda instâncias na Justiça do Rio de Janeiro, que considerou haver identidade entre as duas canções nos dez primeiros compassos, evidenciando-se cópia. A Terceira Turma do STJ manteve a condenação, ao rejeitar o agravo regimental apresentado pelos advogados de Roberto Carlos. O ex-presidente do STJ, ministro Paulo Costa Leite, havia confirmado decisão da Terceira Turma, que dera razão ao despacho do relator, ministro Carlos Alberto Menezes Direito. Ao confirmar que o recurso não poderia ser reapreciado pelo Supremo, o ministro Paulo Costa Leite explicou que o recurso não merecia prosseguir, uma vez que a questão constitucional referida pela defesa sequer foi examinada pela Terceira Turma do STJ. "Ademais, o egrégio Supremo Tribunal Federal tem decidido que não cabe recurso extraordinário para o reexame, em concreto, dos pressupostos de admissibilidade de recurso especial". Em maio do ano passado o vice-presidente do STJ, ministro Edson Vidigal, negou novamente a subida do recurso do Supremo Tribunal Federal ao discordar da defesa do cantor "a insurgência não reúne as condições necessárias à sua admissibilidade, uma vez que a controvérsia está restrita aos pressupostos de conhecimento do Recurso Especial interposto perante este STJ, matéria que se exaure na competência desta Corte, e não enseja Recurso Extraordinário", observou. O ministro Ruy Rosado atesta que a juíza ao reconsiderar parcialmente a sua decisão, determinando a republicação da nota, com a inserção, no texto, do último parágrafo omitido, conforme constava da sentença transitada em julgado. "A sentença permaneceu incólume. Com a reconsideração, buscou-se, tão-somente, dar exato cumprimento à sentença, publicando texto ali constante e confirmado pelo Tribunal", afirma o ministro. Ruy Rosado afirma que não verificou a alegada ofensa aos artigos 471 e 620 do Código de Processo Civil como apresentou a defesa de Roberto Carlos, e entendeu o ministro ser correta a decisão do Tribunal de origem que condenou o cantor e compositor por plágio da música "O Careta". 
Fonte:

<http://www.stj.jus.br/sites/STJ/default/pt_BR/Comunica\% $\% \mathrm{C}_{3} \% \mathrm{~A}_{7} \% \mathrm{C}_{3} \% \mathrm{~A}_{3} / \% \mathrm{C}_{3} \% 9$ Altimas-not $\% \mathrm{C}_{3} \%$ ADcias/STJ-mant $\% \mathrm{C}_{3} \%$ A9m-decis $\% \mathrm{C}_{3} \% \mathrm{~A}_{3} \mathrm{O}$-que-condenou-ocantor-Roberto-Carlos--por-pl\%C3\%Argio>. Acesso em: 17 fev. 2019, grifo nosso.

A notícia apresentada acima nos traz informações sobre as etapas que envolveram o processo. Nela, destacamos o trecho em que o STJ reforça a confirmação de plágio: "O Tribunal de Justiça do Rio de Janeiro confirmou que a música 'O Careta', lançada por Roberto Carlos em 1987 pela gravadora CBS é plágio da canção intitulada 'Loucuras de Amor', de autoria do compositor Sebastião Braga." (trecho da notícia na figura 1). Ao fim da notícia, informa-se que o STJ reconheceu como correta a decisão descrita nesse excerto, proferida pelo Tribunal de Justiça do Rio de Janeiro. O apontamento nos serve como representação da sanção organizada (negativa) imposta à ocorrência de plágio.

A seguir, analisamos a interação de usuários do Youtube em torno de um vídeo postado, contendo a canção Loucuras de amor, no qual se questiona a existência de plágio na canção "O careta”. O usuário autor da postagem parece ser defensor da condenação sofrida por Roberto Carlos por plágio. Esse posicionamento se evidencia no início do vídeo, em que se pode ler "ouça com atenção a música de Sebastião Braga, lançada pela Polygran 1983. E veja se ela se parece com alguma música do 'rei’ Roberto Carlos”. Em seguida, o vídeo se desenvolve, apresentando, em tom comparativo, primeiramente a canção de Sebastião Braga e, posteriormente, Roberto Carlos. Nos comentários, é possível encontrar sujeitos sancionando negativamente e positivamente o plágio; as sanções positivas, entretanto, são mais recorrentes.

Os comentários analisados a seguir representam apenas uma parcela dos 294 comentários totais que acompanhavam o vídeo, considerando o momento de coleta para esta análise. Nesta parte da interação, somando a postagem inicial do vídeo, que também carrega sanções, e os comentários selecionados para análise, é possível visualizar 12 sanções sociais difusas positivas impostas à prática e 2 sanções sociais difusas negativas (essa quantidade é suficiente aos nossos interesses de análise). Os nomes dos usuários foram substituídos por etiquetas, a fim de preservar suas identidades. Vejamos:

Figura 2 - Interação e sancionamentos de usuários do youtube em torno das canções Loucuras de amor e $\mathrm{O}$ careta 


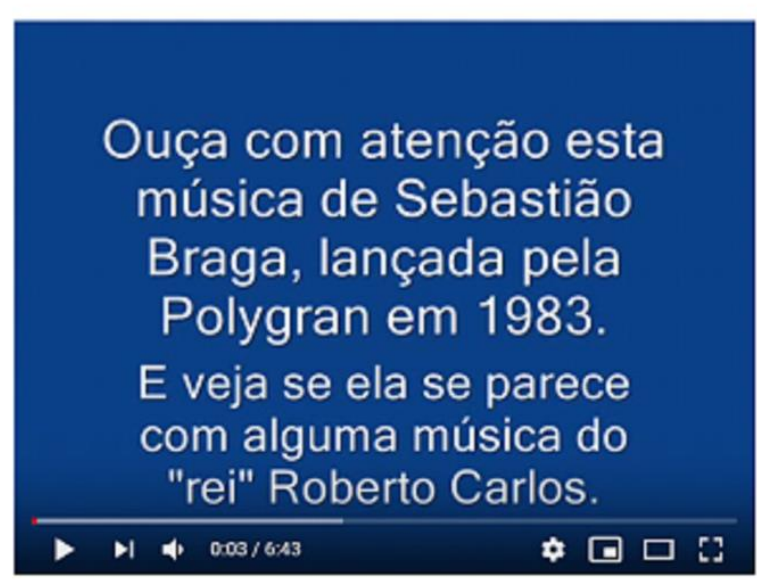

Plágio ou coincidẻncia.wmv

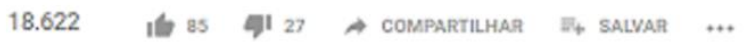

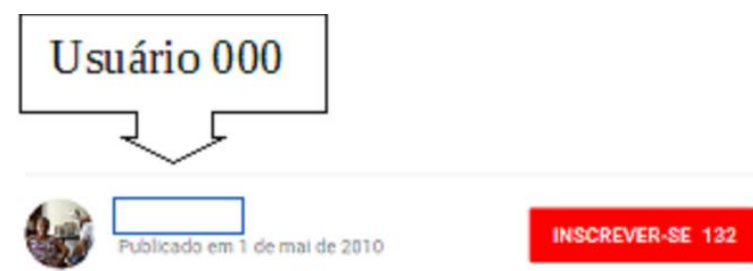

Depois de um lonģo processo na justiça, Robento Carlos teve que desembolsar 2 milhões de reais por causa desta músicas ai.

Categoria Música

Mûsica neste vídeo

Saiba mais

Ouça músicas sem anúncios com o YouTube Premium

Música La Vida Te Ofrece Otras Cosas (O Careta)

Artista Roberto Carlos

Álbum Lines Azul - Vol. VIII - Volver

Licenciado para SME (em nome de Sony Special Products); U日EM, - YouTube por Sony ATV Publishing, LatinAutor e 2 associaçōes de direitos musicais

MOSTRAR MENOS

294 comentários $\equiv$ CLASSIFICAR POR 
Fonte: <https://www.youtube.com/watch?v=h8eSfcGkduk>. Acesso em: 17 abr. 2019.
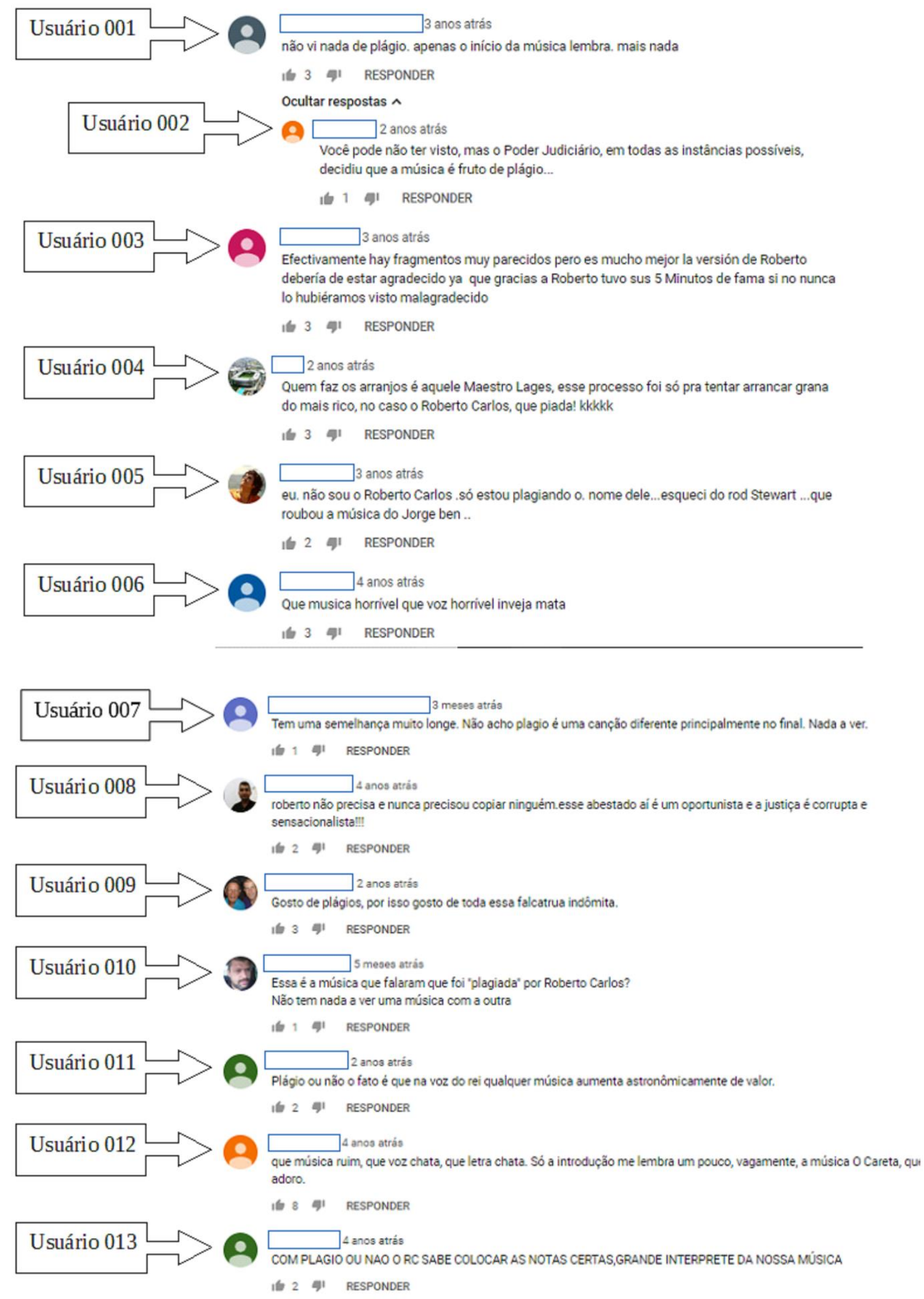

Revista Investigações, Recife, v. 32, n. 2, p. 571 - 602, Dezembro/2019 
Inicialmente, podemos analisar que o internauta ooo, responsável pela postagem do vídeo na plataforma Youtube, sinaliza aos demais que "Depois de um longo processo na justiça, Roberto Carlos teve que desembolsar 2 milhões de reais por causa desta músicas aí [canção O careta].” Tal esclarecimento, somado à solicitação inicial no vídeo, dão o rumo da discussão que se segue nos comentários.

Para além da acusação, portanto, os internautas têm ciência de que pesa sobre a canção não somente acusação de plágio, mas efetiva punição jurídica. Todavia, isso parece não ser suficiente para que os sujeitos reconheçam a ocorrência de plágio e venham a sancioná-la negativamente.

Nesse sentido, o internauta oo1 argumenta "não vi nada de plágio. apenas o início da música lembra. mais nada”. É interessante considerar que, conforme aponta a notícia sobre o processo constante no site do STJ, “A ação foi julgada procedente em primeira e segunda instância na Justiça do Rio de Janeiro, que considerou haver identidade entre as duas canções nos dez primeiros compassos, evidenciando-se cópia”. Logo, tal posicionamento da justiça brasileira aponta para a desmistificação da necessidade de extensa reprodução (e no caso de plágios envolvendo melodias, por exemplo, reprodução de um número específico de compassos) ao se averiguar realização de plágio.

O internauta 002, por sua vez, em resposta ao oo1, contraria sua argumentação de não ter reconhecido, ali, plágio: "Você pode não ter visto, mas o Poder Judiciário, em todas as instâncias possíveis, decidiu que a música é fruto de plágio.... O Usuário internauta apela para a consideração de haver, contra a canção, o que compreendemos como sanção social organizada negativa.

O internauta 003 manifesta-se em espanhol, e, assim, diz: "Efectivamente hay fragmentos muy parecidos pero es mucho mejor la versión de Roberto debería de estar agradecido ya que gracias a Roberto tuvo sus 5 Minutos de fama si no nunca lo hubiéramos visto malagradecido" ${ }^{11}$. Podemos notar, nesse comentário, que, apesar de reconhecer a prática, o sujeito considera a beleza da produção como fator relevante a ser considerado na avaliação de plágio; desse modo, sendo, em sua opinião, a canção de Roberto Carlos melhor, o plágio não teria ocorrido. Para esse internauta, Sebastião Braga, autor afetado

\footnotetext{
11“Efetivamente há muitos fragmentos parecidos, mas é muito melhor a versão de Roberto. Deveria estar agradecido, já que graças a Roberto teve seus 5 minutos de fama, senão nós nunca o teríamos visto, mal-agradecido." (tradução livre).
}

Revista Investigações, Recife, v. 32, n. 2, p. 571 - 602, Dezembro/2019 
pelo plágio, inclusive, deveria ser agradecido pelos minutos de fama supostamente decorrentes do processo.

Entendemos que esse posicionamento, de avaliar a ocorrência direcionando considerações à "beleza" do texto sancionado, possui estreita relação com o fato de tal prática estar situada no gênero canção, domínio literomusical. As práticas de linguagem manifestadas em tal meio, por vezes, possibilitam ser avaliadas utilizando como parâmetro, sobretudo pelo público não especializado, o "belo". Assim, costumeiramente, canções, poemas, contos, romances, são comparadas pelos sujeitos em busca de aferir quais textos seriam mais ou menos belos. Em outros domínios, como o jornalístico, ou científico/acadêmico, apesar de ser possível considerar que abstratamente os textos possuam beleza, essa geralmente não é considerada pelos sujeitos em suas avaliações, que elencam outros parâmetros (como a veracidade das informações, no domínio jornalístico, e a cientificidade das explicações, no domínio científico/acadêmico), ao sancionar as respectivas manifestações textuais.

O internauta 004 argumenta que "esse processo" teria sido somente "pra tentar arrancar grana do mais rico, no caso o Roberto Carlos”. O internauta 005, por sua vez, faz comentário irônico, dizendo não ser Roberto Carlos e que estaria plagiando o nome dele. Além disso, coloca em cena outra acusação de plágio envolvendo Rod Stewart e Jorge Ben Jor. O internauta 006, assim como o o03, argumenta em torno da beleza das canções, proferindo o seguinte comentário sobre a canção Loucuras de amor e sobre a voz de Sebastião Braga: "Que musica horrível que voz horrível inveja mata”.

O internauta 007, tal qual o oo1, aponta semelhança, apesar de distante, entre as canções. Afirma não achar ser plágio, já que as duas são diferentes, especialmente no final. Dessa maneira, tal sujeito se ancora em critério relativamente mais técnico ao proferir seu julgo. O internauta oo8 classifica Sebastião Braga como "oportunista”, na mesma linha argumentativa do Usuário 004, e ressalta ser a justiça brasileira "corrupta e sensacionalista”. O internauta oo9 diz "Gosto de plágios, por isso gosto de toda essa falcatrua indômita." Dessa forma, apresenta seu interesse por produções que, mesmo ilícitas, seriam “indomáveis”.

Nota-se, com base nos comentários dos internautas de 004 e oo8, que a função de autoria ocupada por Roberto Carlos na sociedade exerce forte influência em como os sujeitos compreendem a manifestação da ocorrência. Tal autor é reconhecido por grande 
parcela da população brasileira, haja vista que suas canções possuem presença marcante em nossa cultura. Assim, nessa relação recíproca, o conjunto da obra de Roberto Carlos, considerado qualificado e prestigiado, lhe dá, em nossa sociedade, o poder do dizer (que dá relevância aos seus textos); Roberto Carlos, por sua vez, haja vista essa posição ocupada, dá respaldo aos textos que produz, quer sejam acusados ou não de plágio. É tal relação, portanto, que permite aos referidos internautas avaliar a acusação frisando o prestígio de Roberto Carlos perante Sebastião Braga, já que aquele ocupa posição social de autoria, contrariamente a esse.

O internauta oı questiona "Essa é a música que falaram que foi 'plagiada' por Roberto Carlos?" e, em seguida, se posiciona: "Não tem nada a ver uma música com a outra”. O internauta o11 comenta: "Plágio ou não o fato é que na voz do rei qualquer música aumenta astronomicamente de valor." É interessante que tal comentário se alicerce em torno das relações de poder que envolvem as ocorrências de plágio, como tratamos no parágrafo anterior. Roberto Carlos, músico de relativo prestígio, tanto no Brasil como no exterior, teria a capacidade de elevar o valor, musical ou monetário, das canções que interpreta. Roberto Carlos cumpre uma função autor, perante os demais sujeitos da comunidade. Isso parece justificar o porquê de, em alguns comentários, a canção de Sebastião Braga ser classificada como ruim, em comparação com a canção de Roberto Carlos.

Seguindo tal raciocínio, o internauta o12 diz: "que música ruim, que voz chata, que letra chata. Só a introdução me lembra um pouco, vagamente, a música O Careta, que eu adoro.” Novamente, a argumentação está centrada na beleza musical. Além disso, o internauta reconhece haver proximidade entre as canções, em seus trechos iniciais. Por fim, o Usuário o13 considera que: "COM PLAGIO OU NAO O RC SABE COLOCAR AS NOTAS CERTAS, GRANDE INTERPRETE DA NOSSA MÚSICA”.

Pudemos investigar, nessa breve interação, que a argumentação dos sujeitos em torno da ocorrência de plágio deu-se com base em apontamentos que envolveram a beleza das canções, a breve proximidade entre as músicas analisadas, os supostos interesses monetários, e a suposta busca por fama do autor plagiado. Os internautas, com exceção do ooo e do 002, desconsideraram, assim, a sanção judicial sobre a prática.

Cabe reforçar que o domínio discursivo literomusical tem como uma de suas características a prevalência da liberdade poética em prol de propósitos artísticos. Muitas Revista Investigações, Recife, v. 32, n. 2, p. 571 - 602, Dezembro/2019 
vezes, a recepção do público perante determinadas produções literomusicais é focada na estética de tais textos e em como esses foram influenciados e influenciaram o comportamento sociocultural de sua época. Tal realidade tem forte influência nas sanções proferidas pelos sujeitos, de forma individual, a ocorrências de plágio nesse domínio. Por outro lado, é preciso considerar ainda que nesse meio as relações autorais são recorrentemente postas em destaque (as primeiras demarcações de autoria, conforme discutimos na seção "O plágio como fenômeno social”, inclusive, são demandadas e se efetivam no meio literário). Assim, a vinculação de um autor a sua obra é sempre explicitada. Tal realidade, por sua vez, explica o porquê de, especialmente no meio jurídico, ocorrências de plágio no domínio discursivo literomusical não serem abrandadas (tal qual pudemos analisar no exemplo), contrariando, muitas vezes, as sanções proferidas pelos sujeitos particularmente (cf. interação dos internautas).

Para nossa pesquisa, a sanção jurídica que penaliza a canção de Roberto Carlos corresponde, conforme aponta Radcliffe-Brown (1970), tal qual discutimos nas seções anteriores, à sanção social organizada negativa. As avaliações individualmente proferidas pelos usuários, analisadas acima, podem ser consideradas sanções sociais difusas, sendo, em sua maioria, positivas. Em meio aos comentários analisados, somente um dos internautas mostrou posicionamento favorável à penalização por plágio, realizada pela justiça. Nesse sentido, podemos caminhar rumo à compreensão de como as sanções sociais impostas ao plágio podem variar, conforme o domínio discursivo em que as ocorrências de plágio se dão. É importante lembrar também que, de acordo com o que frisamos anteriormente, a conceituação e compreensão do plágio está fortemente ligada a relações de poder envolvendo autores, obras e demais sujeitos sociais.

No exemplo analisado, podemos analisar que a correspondência entre as sanções organizadas e difusas se mostraram mínimas. A avaliação organizada sancionou negativamente a prática; já as avaliações individuais mostraram tendência a sancionar positivamente, em detrimento da canção plagiada. Há de se reconhecer ainda que, sendo o plágio uma prática polêmica, mesmo em meio às sanções difusas, houve apontamentos contrários ao exposto como tendência (o que, por sua vez, não anula a tendência analisada).

Ao fim desta análise, cabe apresentar o trecho da canção motivador da acusação de plágio. Como pudemos compreender, a acusação se dirigiu à parte melódica dos textos, o Revista Investigações, Recife, v. 32, n. 2, p. 571 - 602, Dezembro/2019 
que limita nossa possibilidade de verificação dos movimentos apropriados pela ocorrência que levaram às sanções. Entretanto, realizamos a distribuição da versificação dos versos, a fim de apontar a semelhança da métrica e da prosódia de tais trechos, o que possibilitaria compreendê-las como reprodução, em termos intertextuais.

Figura 3 - Distribuição da versificação dos trechos analisados

\begin{tabular}{|c|c|}
\hline \multirow[b]{2}{*}{$\begin{array}{l}\text { Canção } \\
\text { Loucuras de } \\
\text { Amor, } \\
\text { Sebastião } \\
\text { Braga }\end{array}$} & $\begin{array}{l}\text { Deixe esse medo criança que existe entre nós, } \\
\text { amar é como uma dança, é como soltar a voz }\end{array}$ \\
\hline & 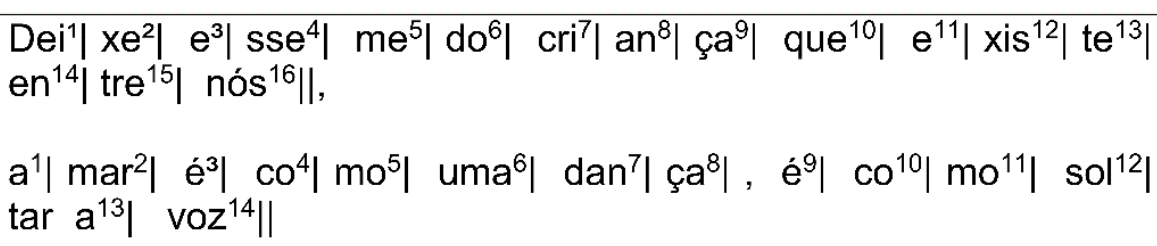 \\
\hline \multirow[b]{2}{*}{$\begin{array}{c}\text { Canção O } \\
\text { careta, Roberto } \\
\text { Carlos }\end{array}$} & medo sabendo \\
\hline & 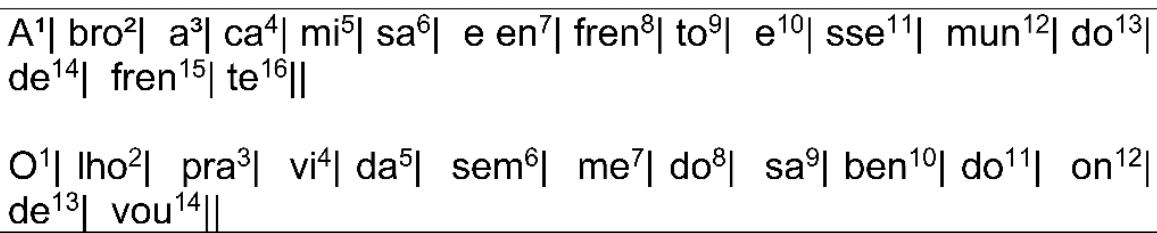 \\
\hline
\end{tabular}

Fonte: elaboração própria, 2019.

É possível apontar que, caso a melodia tenha a mesma cadência analisada nesta organização rítmica e prosódica, a relação intertextual pode ser aferida. Nesse sentido, argumentamos a importância de estreitamento da Linguística Textual com os estudos voltados a outras semioses, que não somente a verbal, ou mesmo a imagética (que já representam avanços), a fim de captar ferramentas para análise de casos como esse.

Caso II: acusação de plágio no gênero notícia

Neste ponto, analisamos uma acusação de plágio encontrada no domínio discursivo jornalístico, no gênero notícia. O caso foi noticiado pelo Jornal Opção (Goiás), que, por sua vez, acusava o jornal O Popular (Goiás) de ter plagiado um de seus textos jornalísticos. A notícia de acusação apresentava, em tom de comparação, as duas notícias (sendo a primeira, de autoria do Jornal Opção, tida como texto-fonte, e a segunda, de 
autoria do jornal O Popular, tida como texto-plágio). O texto a seguir consiste na notícia de acusação, de autoria do Jornal Opção. Vejamos:

Figura 4 - notícia de acusação: plágio no domínio jornalístico

O Popular plagia reportagem do Jornal Opção a respeito de estupro na Câmara Municipal de Goiânia

02/03/2017 10h16

Por Euler de França Belém

Edição 2172

Como o jornal não citou a fonte inspiradora de sua reportagem, cabe, dado o plágio explícito, até processo judicial

A repórter Amanda Damasceno, do Jornal Opção Online, publicou uma matéria "Assessora parlamentar sofre tentativa de estupro dentro da Câmara de Goiânia" a respeito de uma violência ocorrida na sede do Legislativo da capital. Poucas horas depois, "O Popular" divulgou o mesmo assunto. Mas a parte final da reportagem é uma cópia literal da reportagem do Jornal Opção.

O jornalista do "Pop" sequer "cozinhou" o texto - optou pelo mais fácil, a transcriação [sic] literal, que, como não citou a fonte, trata-se de crime. Cabe, portanto, ação judicial tanto contra "O Popular" quanto contra o profissional. O plágio fere o direito autoral e a ética profissional.

Veja abaixo o texto de O Popular e o texto do Jornal Opção - confira como o primeiro foi literalmente plagiado pelo segundo:

$[\ldots]$

Fonte: <https://www.jornalopcao.com.br/colunas-e-blogs/imprensa/o-popular-plagiareportagem-jornal-opcao-respeito-de-estupro-na-camara-municipal-de-goiania88463/>. Acesso em: o7 maio 2018.

Destacamos, no quadro abaixo, a comparação entre as duas notícias, tratadas no noticiamento, sendo a primeira a considerada como texto-fonte, a segunda como textoplágio. Em verde, estão grifados os trechos em que podemos constatar o plágio pelos movimentos de citação (copresença, reprodução e captação). Em amarelo, grifamos os trechos em que constatamos o plágio pelos movimentos da paráfrase (copresença, reprodução + adaptação e captação). Consideramos que tais movimentos, por se expressarem no cotexto, tenham levado, de forma mais imediata, à acusação de plágio. Vejamos: 
Figura 5 - Comparação: notícia-fonte, notícia acusada de plágio

\begin{tabular}{|c|c|}
\hline TEXTO-FONTE & TEXTO ACUSADO DE PLÁGIO \\
\hline 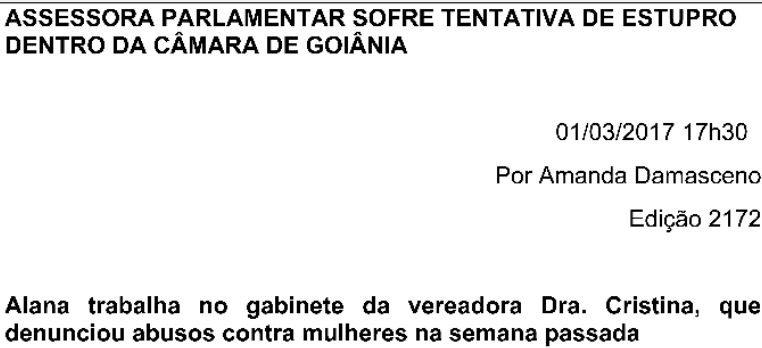 & $\begin{array}{l}\text { Mulher é atacada dentro de banheiro da Câmara Municipal de } \\
\text { Goiânia } \\
\text { O agressor estava escondido em uma das cabines do banheiro } \\
\text { feminino e tentou entrar por debaixo da porta onde estava a vítima }\end{array}$ \\
\hline $\begin{array}{l}\text { Na tarde desta quarta-feira }(1 \% / 3) \text {, uma assessora da vereadora Dra. } \\
\text { Cristina Lopes (PSDB) sofreu tentativa de estupro dentro da Câmara } \\
\text { Municipal de Goiânia. A jovem foi ao banheiro feminino quando } \\
\text { um homem a atacou. } \\
\text { Ao Jornal Opção, a parlamentar contou que o agressor estava } \\
\text { escondido em uma das cabines. A assessora, chamada Alana, entrou } \\
\text { no banheiro e se dirigiu a uma cabine ao lado, quando ele tentou, } \\
\text { então, entrar por debaixo da porta. Gritando, ela saiu correndo do } \\
\text { banheiro. } \\
\text { Ao escutar os gritos, o vereador Zander Fábio (PEN) saiu de seu } \\
\text { gabinete e conseguiu segurar o homem. Em seguida, a Guarda Civil } \\
\text { Metropolitana foi chamada e levou o suspeito algemado para a } \\
\text { delegacia. }\end{array}$ & $\begin{array}{l}\text { A vereadora Dra. Cristina Lopes (PSDB) relatou ao POPULAR que uma } \\
\text { assessora de seu gabinete sofreu uma tentativa de ataque na tarde } \\
\text { desta quarta-feira }\left(1^{\circ}\right) \text { na Câmara Municipal de Goiânia. De acordo com } \\
\text { a parlamentar, o agressor estava escondido em uma das cabines do } \\
\text { banheiro feminino e tentou, então, entrar por debaixo da porta onde } \\
\text { estava Alana. } \\
\text { A vítima gritou e saiu correndo do banheiro. Ao escutar os gritos, o } \\
\text { vereador Zander Fábio (PEN) saiu de seu gabinete e conseguiu segurar } \\
\text { o homem. A Guarda Civil Metropolitana foi chamada em seguida e levou } \\
\text { o suspeito para a delegacia, que alegou que havia "entrado no banheiro } \\
\text { errado, por engano". Segundo a Guarda Civil, o homem aparentava } \\
\text { embriaguez. }\end{array}$ \\
\hline $\begin{array}{l}\text { Segundo informações preliminares, o agressor seria um morador em } \\
\text { situação de rua e estaria alcoolizado. } \\
\text { Em sua página no Facebook, o vereador Jorge Kajuru (PRP) denunciou } \\
\text { o caso. "Um homem cafajeste entrou na Câmara e não poderia entrar. } \\
\text { Ele foi ao banheiro feminino e cometeu este crime", afirmou. } \\
\text { O parlamentar ressaltou, ainda, que se o suspeito tivesse escapado, não } \\
\text { haveria nenhuma imagem dele, já que as câmeras da Casa não estão } \\
\text { funcionando. Ele afirmou, ainda, que o presidente da Câmara, Andrey } \\
\text { Azeredo (PMDB), disse que irá solucionar o problema. } \\
\text { Dra. Cristina ressaltou que na última semana já havia denunciado que } \\
\text { as mulheres vinham sido assediadas dentro da Casa. "Precisamos ter } \\
\text { mais segurança. A Câmara está vulnerável, é perigoso. Essa foi uma } \\
\text { tragédia anunciada. A Alana está aos prantos, não está nem } \\
\text { conseguindo falar", disse. } \\
\text { Após a denúncia feita na última terça-feira (21/2), Andrey Azeredo } \\
\text { classificou a situação como "inaceitável" e prometeu "ação firme" contra } \\
\text { qualquer tipo de abuso. "Sabemos do constrangimento mas precisamos } \\
\text { de ser comunicados formalmente, pois isso é caso de polícia", disse. }\end{array}$ & $\begin{array}{l}\text { O vereador Jorge Kajuru (PTN) denunciou o caso em sua página do } \\
\text { Facebook: "Um homem cafajeste entrou na Câmara e não poderia } \\
\text { entrar. Ele foi ao banheiro feminino e cometeu este crime", afirmou. } \\
\text { Dra. Cristina ressaltou que já havia denunciado, na última semana, que } \\
\text { as mulheres vinham sendo assediadas dentro da Casa. "Precisamos ter } \\
\text { mais segurança. A Câmara está vulnerável, é perigoso. Essa foi uma } \\
\text { tragédia anunciada. A Alana está aos prantos, não está nem } \\
\text { conseguindo falar", disse. } \\
\text { Após a denúncia feita na última terça-feira (21/2), Andrey Azeredo } \\
\text { classificou a situação como "inaceitável" e prometeu "ação firme" contra } \\
\text { qualquer tipo de abuso. "Sabemos do constrangimento mas precisamos } \\
\text { de ser comunicados formalmente, pois isso é caso de policia", disse. }\end{array}$ \\
\hline
\end{tabular}

Notícia 1 (texto-fonte). Fonte: <https://www.jornalopcao.com.br/ultimasnoticias/assessora-parlamentar-sofre-tentativa-de-estupro-dentro-da-camara-degoiania-88436/>. Acesso em: o7 maio 2018.

Notícia 2 (texto acusado de plágio). Fonte:

$<$ https://www.opopular.com.br/noticias/cidades/mulher-\% $3 \%$ A9-atacada-dentro-debanheiro-da-c\%C3\%A2mara-municipal-de-goi\%C3\%A2nia-1.1233629>. Acesso em: 07 maio 2018.

Sobre a sanção desta ocorrência de plágio, podemos analisar que os sujeitos responsáveis pela acusação, apesar de terem reconhecido o plágio e o denunciado, Revista Investigações, Recife, v. 32, n. 2, p. 571 - 602, Dezembro/2019 
apontam que a sanção não chegou às instâncias jurídicas. Desse modo, eles afirmam que, frente à ação “Cabe, portanto, ação judicial tanto contra 'O Popular' quanto contra o profissional. O plágio fere o direito autoral e a ética profissional." (trecho da notícia na figura 4). Observando a circulação de notícias na sociedade, percebemos que é comum ocorrências semelhantes a aqui analisada, em que reportagens copiam ou parafraseiam trechos de outras (de conteúdo comum), sem referência à autoria. Com isso, mobilizam os movimentos desses processos intertextuais, mas se apropriam deles para a prática do plágio, não recebendo, porém, sanções sociais negativas. Entretanto, isso não significa dizer que não haja casos constatados, averiguados e sancionados.

O domínio discursivo jornalístico possui como particularidade o fato de ser centrado na produção e circulação de informações tidas como de interesse público. Logo, as produções textuais desse domínio acabam por se tornarem efêmeras, sendo produzidas e propagadas com demasiada rapidez, sobretudo na contemporaneidade, com o advento da internet.

Como toda produção textual, os textos que nascem e circulam nesses domínios não deixam de possuir autoria. Entretanto, na maioria das vezes, as relações autorais são deixadas de lado, em prol do foco no que se noticia. Essa condição contribui para que possamos compreender a realidade citada acima, trechos que carregam as mesmas informações, referentes aos mesmos fatos, sob a mesma organização textual (tendo os mesmos cotextos e contextos, se não, semelhantes). Desse modo, agências de notícias no mundo todo exportam matérias para os mais diversos jornais. Na maior parte das vezes, o texto é muito semelhante ou praticamente idêntico, havendo a modificação apenas do título da notícia, ou de excertos específicos. Esses casos, em outros domínios discursivos, poderiam facilmente ser enquadrados como ocorrências de plágio, mas, aqui, geralmente não o são.

Essas particularidades do domínio em questão servem de base para explicarmos os motivos de acusações de plágio no domínio discursivo jornalístico recorrentemente não ganharem força (conforme mostram os exemplos que analisamos nesta dissertação), seja no meio jurídico ou administrativo, seja recebendo sanções individuais pelos sujeitos. Logo, no domínio jornalístico, uma organização textual parece não bastar para que se possa sancionar determinadas produções como sendo, ou contendo, plágio. Na ocorrência analisada, essa não corporificação pode ser constatada ao verificarmos que não houve Revista Investigações, Recife, v. 32, n. 2, p. 571 - 602, Dezembro/2019 
sanções organizadas, ou mesmo difusas (com exceção da própria acusação), impostas à acusação (o que, inclusive, torna a presente análise mais curta que a anterior, centrada no domínio literomusical, gênero canção). Posto que seja possível aferir que uma notícia se apropriou da outra em prol de sua construção, sem referenciar autoria, o que figuraria plágio, levanta-se apenas a possibilidade de tal acusação chegar ao meio jurídico, vindo a ser sancionada e possivelmente punida.

As reflexões traçadas nesta seção apontam para a tendência de que, no domínio jornalístico, especialmente no gênero notícia, são escassas as sanções proferidas ao plágio, sejam organizadas, sejam difusas. Nesse sentido, nem sempre a acusação de plágio ganha fôlego no meio jornalístico. O gênero notícia tem como uma de suas características a efemeridade, sendo objetivo e de rápida propagação, pois é constituído por textos projetados para informar situações do dia a dia de uma sociedade. Consideramos que essa norma de circulação é fato condicionante para a realidade analisada neste caso. Desse modo, parece-nos que as sanções positivas ou negativas às ocorrências são neutralizadas, como no exemplo que investigamos, em decorrência das regras que orientam os textos pertencentes ao gênero. Por isso, como no caso II, os sujeitos, sobretudo nesse domínio e nesse gênero, por mais que reconheçam a prática, através das marcas intertextuais, não as sancionam.

\section{Considerações finais}

Constatamos, neste trabalho (e nos estudos que temos desenvolvido relativos à temática, cf. Souza Santos 2018, Souza Santos 2019, Souza Santos e Cavalcante 2019 e Souza Santos e Nobre 2019), que nem sempre as sanções proferidas à prática, sejam organizadas ou difusas, tenderão à negatividade (forma de sanção mais esperada às práticas consideradas não lícitas, como o plágio). Associamos a variação de tais sanções ao fato de o plágio, ao ser inserido em determinado gênero, infringir as normas de circulação daquele gênero específico, que, por sua vez, se organiza de forma particular, associada ao domínio discursivo do qual o gênero emerge e por onde ele circula. Assim, projetamos que valores ideológicos diferentes, advindos de práticas discursivas diferentes, levam a compreensões diferentes das infrações e, consequentemente, a sanções diferentes das ocorrências. 
No primeiro caso analisado, uma acusação de plágio inserido no gênero canção constatou-se que as sanções difusas à prática tenderam a ser positivas, contrariando as sanções organizadas, que se apresentaram negativas. Ao avaliar a ocorrência, os sujeitos levaram em consideração, principalmente, a beleza das canções (considerando ser o texto-plágio mais belo que o texto-fonte), possíveis interesses monetários do sujeito acusador frente ao sujeito acusado, e a breve proximidade entre o texto-fonte e o textoplágio. No segundo caso, o texto que realiza a acusação de plágio apenas projeta a possibilidade de a ocorrência sofrer sanção social organizada negativa; a própria acusação do jornal, por sua vez, pode ser compreendida como uma sanção social difusa, que, apesar de ser negativa, não ganha corpo. Desse modo, parece haver uma neutralização às sanções, tanto organizadas quanto difusas, apesar de os sujeitos reconhecerem constitucionalmente a prática. Associamos a neutralização de tais sanções ao gênero em que a prática está inserida, haja vista serem traços da notícia a efemeridade e o foco no repasse de informações.

É importante destacar ainda que no domínio jornalístico, gênero notícia, a falta de mais sanções que pudessem confirmar ou refutar a tendência dos atos sancionatórios proferidos ao plágio, que porventura viessem a representar uma falha investigativa deste trabalho (por sua análise não seguir a realizada no gênero canção, haja vista que não avaliamos sanções jurídicas ou manifestadas em comentários, por exemplo), na verdade, mostrou-se como uma realidade determinante para que possamos compreender como se dão as sanções ao plágio nesses domínios e gênero. Em tal meio, conforme apontamos no parágrafo anterior, as sanções impostas ao plágio aparentam se corporificar pela organização do domínio e regras do gênero.

Logo, é possível apontar que socialmente a compreensão do que é, ou não, plágio, mostra-se com estritamente relacionada ao espaço em que a prática ocorre. Essa realidade repercute fortemente na busca de coibição da prática e nos embates argumentativos entre defesas e acusações de ocorrências.

Concluirmos, assim, que as marcas do plágio (o que o caracteriza enquanto fenômeno linguístico: textual e discursivo, além de social) se relacionam não somente à formalidade estritamente intertextual, mas também à ilicitude, ao sancionamento e à transgressão das regras dos gêneros, à infração às relações autorais de poder, aos efeitos de sentidos produzidos, à tomada da responsabilidade enunciativa alheia e à mobilização 
de processos intertextuais mais ou menos recorrentes que visam ao apagamento da prática. Esse modo de caracterização, que está atrelado não somente a critérios intertextuais, pode se repetir em outros processos intertextuais (a exemplo das paródias, que, ao serem analisadas, implicam a necessidade de se refletir sobre o humor, ironia, crítica social etc.). Além disso, a organização do plágio, que se dá incorporando movimentos de outros processos intertextuais, não lhe é particular, sendo assim também em outros processos intertextuais, tal qual o que ocorre, por exemplo, nas derivações, ao incorporarem movimentos de copresenças (FARIA, 2014).

\section{Referências}

BAKHTIN, Mikhail. Estética da criação verbal. Tradução de Maria Ermantina Galvão G. Pereira. 1997.

BARTHES, Roland. A morte do autor. O rumor da língua, v. 2, p. 57-64, 2004.

BAZERMAN, Charles. Gêneros textuais, tipificação e interação. Cortez, 2005.

BRASIL. Código Penal Brasileiro (Decreto-lei no 2.848, de 7 de dezembro de 1940). República Federativa do Brasil. Disponível em:

<http://www.planalto.gov.br/ccivil_03/decreto-lei/del2848compilado.htm>. Acesso em: 12 jun. 2019.

BRASIL. Lei no 10.695, de 1ํ de julho de 2003. República Federativa do Brasil. Disponível em: <http://www.planalto.gov.br/ccivil_03/LEIS/2003/L10.695.htm>. Acesso em: 12 jun. 2019.

CAVALCANTE, Mônica Magalhães. Os sentidos do texto. São Paulo: Contexto, 2012. .; BRITO, Mariza Angélica Paiva. Intertextualidades, heterogeneidades e referenciação. Linha D'Água, v. 24, n. 2, p. 83-100, 2011.

CHAVES, Antônio. Plágio. Revista de Direito PGE-GO, v. 16, 2013 [1981].

CHRISTOFE, Lilian. Intertextualidade e plágio: questões de linguagem e autoria. 1996.

DINIZ, Debora; MUNHOZ, Ana Terra Mejia. Cópia e pastiche: plágio na comunicação científica. Argumentum, v. 3, n. 1, p. 11-28, 2011.

FARIA, Maria da Graça dos Santos. Alusão e citação como estratégias na construção de paródias e paráfrases em textos verbo-visuais. 2014. $118 \mathrm{f}$. Tese (Doutorado em Linguística). Programa de Pós-graduação em Linguística, Universidade Federal do Ceará, Fortaleza, 2014.

FISCHER, Rosa Maria Bueno. Foucault. In: OLIVEIRA, Luciano Amaral (org.). Estudos do Discurso: perspectivas teóricas. São Paulo: Parábola, p. 123-151, 2013.

FOUCAULT, Michael. O que é um autor?. In: . Ditos e Escritos: Estética - literatura e pintura, música e cinema (vol. III). Rio de Janeiro: Forense Universitária, 2001. p. 264-298. 
GENETTE, Gérard. Palimpsestos: a literatura de segunda mão. Extratos traduzidos por Cibele Braga; Erika Viviane Costa Vieira; Luciene Guimarães; Maria Antônia Ramos Coutinho; Mariana Mendes Arruda; Mirian Vieira. Belo Horizonte: Viva Voz, 2010.

.; BENTES, Anna Christina; CAVALCANTE, Mônica Magalhães. Intertextualidade: diálogos possíveis. 2. ed. São Paulo: Cortez Editora, 2008.

MARCUSCHI, Luiz Antônio. Processos de produção textual. Produção textual, análise de gêneros e compreensão, 2008.

MUNHOZ, Ana Terra Mejia; DINIZ, Debora. Nem tudo é plágio, nem todo plágio é igual: infrações éticas na comunicação científica. Argumentum, v. 3, n. 1, p. 50-55, 2011.

NOBRE, Kennedy Cabral. Critérios classificatórios para processos intertextuais. 2014. 128 f. Tese (Doutorado em Linguística). Programa de Pós-graduação em Linguística, Universidade Federal do Ceará, Fortaleza, 2014.

PIÈGAY-GROS, Nathalie. Introduction à l'intertextualité. Paris: Dunod, 1996. Traduzido por Mônica Magalhães Cavalcante; Mônica Maria Feitosa Braga Gentil; Vicência Maria Freitas Jaguaribe. São Paulo: Interseções, 2010.

RADCLIFFE-BROWN, Alfred. Sanções sociais, In: PIERSON, Donald. Estudos de Organização Social (Tomo II). São Paulo: Livraria Martins Editôra, 1970.

SANT'ANNA, Affonso Romano de. Paródia, Paráfrase \& Cia. 7. ed. São Paulo: Ática, 2003. SOUSA-SILVA, Rui; ABREU, Bruna Batista. Plágio: um problema forense. Language and Law / Linguagem e Direito, v. 2, n. 2, p. 90-113, 2015.

SOUZA SANTOS, José Elderson de. Plágio como processo intertextual. 2018. 76 f. Projeto de Dissertação (Mestrado em Linguística). Programa de Pós-graduação em Linguística, Universidade Federal do Ceará, Fortaleza, 2018.

Caracterização de traços intertextuais do plágio e análise de sanções socialmente impostas. 2019. 144 f. Dissertação em andamento (Mestrado em Linguística). Programa de Pósgraduação em Linguística, Universidade Federal do Ceará, Fortaleza, 2019.

.; CAVALCANTE, Mônica Magalhães. O plágio sob uma ótica textual-discursiva. In: I Jornada de Linguística Textual: Diálogos em Estudo da Linguagem, 2019, São Luís. Anais... São Luís: I Jornada de Linguística Textual: Diálogos em Estudo da Linguagem, 2019. p. 296-309.

.; NOBRE, Kennedy Cabral. Intertextualidades explícitas e intertextualidades implícitas. Signótica, v. 31, 2019.

ZAVAM, Aurea. Por uma abordagem diacrônica dos gêneros textuais: um estudo com editoriais de jornal. Fortaleza: Imprensa Universitária, 2017. 
* Mestrando pelo Programa de Pós-Graduação em Linguística da Universidade Federal do Ceará.

** Professora Adjunto da Universidade da Integração Internacional da Lusofonia Afrobrasileira (UNILAB), campus Redenção, e professora do Mestrado Interdisciplinar em Humanidades (MIH/UNILAB). Bolsista de Produtividade em Pesquisa da FUNCAP (BPI).

*** Professora Associado IV da Universidade Federal do Ceará e bolsista CNPq de Produtividade em Pesquisa nível PQ-2. 